Repository of the Max Delbrück Center for Molecular Medicine (MDC) Berlin (Germany)

\title{
Potent Inhibitory Activity of Chimeric Oligonucleotides Targeting Two Different Sites of Human Telomerase
}

Dr. Eckart Matthes, Christine Lehmann, Marianne Stulich, Yong Wu, Lora Dimitrova, Eugen Uhlmann, Martin Von Janta-Lipinski

This is a copy of an article published in the "Oligonucleotides" () 2005 copyright Mary Ann Liebert, Inc.; "Oligonucleotides" is available online at: http://online.liebertpub.com. 


\title{
Potent Inhibitory Activity of Chimeric Oligonucleotides Targeting Two Different Sites of Human Telomerase
}

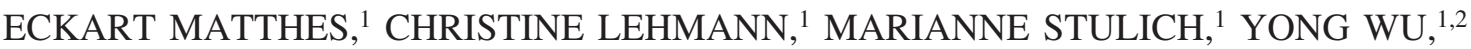 \\ LORA DIMITROVA, ${ }^{1}$ EUGEN UHLMANN,${ }^{3}$ and MARTIN VON JANTA-LIPINSKI ${ }^{1}$
}

\begin{abstract}
Suppression of telomerase activity in tumor cells has been considered as a new anticancer strategy. Here, we present chimeric oligonucleotides (chimeric ODNs) as a new type of telomerase inhibitor that contains differently modified oligomers to address two different sites of telomerase: the RNA template and a suggested protein motif. We have shown previously that phosphorothioate-modified oligonucleotides (PS ODNs) interact in a length-dependent rather than in a sequence-dependent manner, presumably with the protein part of the primer-binding site of telomerase, causing strong inhibition of telomerase. In the present study, we demonstrate that extensions of these PS ODNs at their $3^{\prime}$-ends with an antisense oligomer partial sequence covering 11 bases of the RNA template cause significantly increased inhibitory activity, with $\mathrm{IC}_{50}$ values between 0.60 and $0.95 \mathrm{nM}$ in a Telomeric Repeat Amplification Protocol (TRAP) assay based on U-87 cell lysates. The enhanced inhibitory activity is observed regardless of whether the antisense part is modified (phosphodiester, PO; 2'-O-methylribosyl, 2'-OMe/PO; phosphoramidate, PAM). However, inside intact U-87 cells, these modifications of the antisense part proved to be essential for efficient telomerase inhibition 20 hours after transfection. In particular, the chimeric ODNs containing PAM or 2'-OMe/PO modifications, when complexed with lipofectin, were most efficient telomerase inhibitors (ID $_{50}=0.04$ and $0.06 \mu \mathrm{M}$, respectively). In conclusion, ODNs of this new type emerged as powerful inhibitors of human telomerase and are, therefore, promising candidates for further investigations of the anticancer strategy of telomerase inhibition.
\end{abstract}

\section{INTRODUCTION}

$\mathbf{I}_{\mathrm{p}}^{\mathrm{n}}$ HAS BEEN SHOWN THAT most human tumors overexpress telomerase (Shay and Wright, 1996). Therefore, activation of telomerase is considered an essential component for the unlimited proliferative activity of cancer cells (Hahn et al., 1999; Zhang et al., 1999). This enzyme compensates for the loss of telomeric DNA at the ends of chromosomes, which occurs during each round of DNA replication. Thus, cancer and other immortal cells appear to be capable of escaping growth arrest and apoptosis which are triggered when telomeric DNA ends reach a critical length. Long-term inhibition of telomerase activity has, therefore, gained considerable interest as a promising strategy to change the immortal state of cancer cells to a mortal one (Autexier, 1999). In fact, it has been shown that disruption of the catalytic function of telomerase by mutations abolishes the tumorigenicity of human tumor cells in vivo (Hahn et al., 1999).

Human telomerase is composed of two essential components, the catalytic protein subunit with reverse transcriptase activity (hTERT) (Lingner et al., 1997; Counter

\footnotetext{
${ }^{1}$ Max-Delbrück-Centrum für Molekulare Medizin, D-13125 Berlin, Germany.

${ }^{2}$ Present address: Central Southern University, Third Xiangya Hospital, Changsha, 410013 Hunan, P. R. China.

${ }^{3}$ Sanofi-Aventis Pharma, Deutschland GmbH, D-65926 Frankfurt am Main, Germany. Present address: Coley Pharmaceutical GmbH, D-40764 Langenfeld, Germany.
} 
et al., 1997) and the endogeneous RNA subunit (Feng et al., 1995). In principle, either of these two subunits might be targeted to inhibit telomerase enzyme activity. An attractive target is the telomerase RNA part, especially the 11-nucleotide (nt) region used as template for synthesis of new telomeric DNA, as it can be targeted by a corresponding complementary nucleic acid, such as an antisense agent. Thus, the expression of antisense RNA in immortal human cells has been shown to induce not only telomere shortening but also cell death, beginning after 23-26 cell doublings (Feng et al., 1995).

These results have, thus, initiated a growing number of studies using oligonucleotides (ODNs) as potential inhibitors of telomerase activity, including hammerhead ribozymes (Kanazawa et al., 1996; Wan et al., 1998), unmodified antisense ODNs (Glukhov et al., 1998; Saretzki et al., 1999), 2'5'-oligoadenylate-linked ODNs directing RNase L to cleave telomerase RNA (Kondo et al., 1998, 2001), and 2'-O-methyl (2'-OMe)-modified and 2'-Omethoxyethyl-modified oligoribonucleotides and locked nucleic acid (LNA) oligomers (Pitts and Corey, 1998; Elayadi et al., 2001, 2002). Peptide nucleic acids (PNAs) proved to be most effective (Norton et al., 1996), and their efficiency may be increased further by conjugation with cationic peptides (Harrison et al., 1999).

At the cellular level, PNAs duplexed with DNA and 2 '-OMe RNAs have been described as most effective inhibitors of telomerase activity. In these PNA/DNA partial duplex molecules, the DNA portion allows for efficient transfection by means of cationic lipids (Hamilton et al., 1999; Elayadi et al., 2001). Furthermore, long-term treatment with $2^{\prime}$-OMe-RNA derivatives or $\mathrm{N}^{\prime} \rightarrow$ P5' phosphoramidate (PAM) analogs was found to cause telomere shortening, followed by cellular senescence and apoptosis in tumor cells (Herbert et al., 1999, 2002). Controversal results, however, have been reported for Grich phosphorothioate-modified ODNs (PS ODNs). They were found to be less potent and selective than PNAs (Norton et al., 1996), and their efficacy was thought to be dependent on their ability to form G-quartets (Sharma et al., 1997). In addition, they have been reported to exert a direct growth-inhibiting effect on cell proliferation (Mata et al., 1997; Ohnuma et al., 1997).

We have described that PS ODNs, although designed to bind via Watson-Crick base pairing to the RNA template, bind in a sequence-independent manner to telomerase protein, which could explain some of the conflicting results (Matthes and Lehmann, 1999). The telomerase protein hTERT is thought to have a specific site to fix the $5^{\prime}$-end of the primer, called primer binding site, which appears to be required for a processive telomeric DNA synthesis (Hammond et al., 1997). We have previously suggested a model in which PS ODNs bind with high affinity to this primer binding site, causing strong competitive inhibition of primer binding to telomerase (Matthes and Lehmann,
1999). The efficiency of the PS ODNs in inhibiting telomerase activity of HL-60 cell lysates proved to be length dependent rather than sequence dependent. Maximum inhibition was reached with a 20-mer PS ODN, which could barely be increased by longer ODNs but could be decreased with decreasing length of the PS-ODN, resulting in almost complete loss of inhibitory activity at the length of a 6-mer PS ODN (Matthes and Lehmann, 1999).

Nonsequence-specific effects of PS ODNs frequently are considered as a disadvantage for the application of PS ODNs. However, the unique structure and function of telomerase should allow the design of oligomers consisting of PS ODNs extended at the $3^{\prime}$-terminus by an oligomer, hybridizing effectively to the neighboring template region of RNA.

In this study, we have designed and studied chimeric ODNs that combine protein-binding and RNA-binding properties, thus retaining the high efficiency of PS ODNs but providing the required specificity by an antisense part. Furthermore, we present evidence that the polyanionic character of PS ODNs and of heparin appears to be responsible for inhibition of telomerase activity. We also describe additive inhibitory effects when PS ODNs are given in combination with antisense ODNs. The novel type of chimeric ODNs, which consist of 10-20-mer PS ODNs extended at the 3 '-end by unmodified or modified antisense ODNs covering all 11 bases of the template site of telomerase RNA, are powerful inhibitors of telomerase activity in vitro and at the cellular level in U-87 glioblastoma cells.

Our strategy to target the primer binding site as well as the RNA template of telomerase by chimeric ODNs was followed by Tarkanyi et al. (2005). These authors used 4thiouridylate-oligomers instead of PS ODNs for binding to the protein site of telomerase. In agreement with our results, they demonstrate that in dependence on the length of the 4-thiouridylate part, chimeric ODNs increase the inhibitory activity of simple antisense ODNs on telomerase activity.

\section{MATERIALS AND METHODS}

\section{Cell incubations and cell extracts}

Human glioblastoma cells U-87 were plated at $9 \times 10^{3}$ cells/well in 24-well plates in EMEM supplemented with $5 \%$ basal medium supplement, $2 \mathrm{mM}$ GlutaMax (Life Technologies, Gaithersburg, MD), 10\% heat-inactivated fetal bovine serum (FBS), $100 \mathrm{U} / \mathrm{ml}$ penicillin, and 100 $\mu \mathrm{g} / \mathrm{ml}$ streptomycin at $37^{\circ} \mathrm{C}$ in a $5 \% \mathrm{CO}_{2}$ atmosphere. Adherent cells were washed twice with phosphatebuffered saline (PBS), trypsinized, counted, lysed with CHAPS buffer (10 mM Tris-HCl, pH 7.5, 1 mM $\mathrm{MgCl}_{2}$, $1 \mathrm{mM}$ EGTA, $0.1 \mathrm{mM}$ benzamidine, $5 \mathrm{mM} \beta$-mercaptoethanol, $0.5 \%$ 3-[(3-cholamidopropyl)dimethyl-ammo- 
nio]-1-propane sulfonate, 10\% glycerol [Intergen, Purchase, NY]) $\left(1 \times 10^{6} / 200 \mu \mathrm{l}\right)$, and centrifuged as described (Matthes and Lehmann, 1999). The supernatants used for the determination of telomerase activity were aliquoted and stored at $-80^{\circ} \mathrm{C}$.

For transient transfection of ODNs, the adherent cells were washed with EMEM and incubated for 4 hours with lipofectin/ODN complex in $0.4 \mathrm{ml}$ EMEM supplemented by $3 \% \mathrm{FBS}$ at $37^{\circ} \mathrm{C}$ and $5 \% \mathrm{CO}_{2}$ in air. To prepare the complex, each of the components-the ODN (up to 10 $\mu \mathrm{M})$ and the lipofectin $(2.5 / 5 \mathrm{mg})$ (Life Technologies) was diluted in $50 \mu \mathrm{l}$ serum-free EMEM according to the manufacturer's instructions. Both solutions were mixed, kept at ambient temperature for 15 minutes and overlaid onto cells (covered with $0.3 \mathrm{ml}$ EMEM/4\% FBS). After removal of the transfecting mixture, the cells were washed $(1 \times 0.3 \mathrm{ml} \mathrm{PBS,} 3 \times 0.25 \mathrm{ml}$ serum containing medium) and further incubated for 20 hours in $1 \mathrm{ml}$ complete EMEM. Cells were washed $(2 \times 0.25 \mathrm{ml}$ PBS $)$, trypsinized, pelleted, washed again $(2 \times 0.25 \mathrm{ml} \mathrm{PBS}$, $1 \times 0.5 \mathrm{ml}$ PBS), counted, lysed, and stored as described.

\section{Oligomers}

All HPLC-purified PS ODNs (for sequences, Scheme 1B; for structures, Scheme 2B) were provided by BioTez (Berlin, Germany) and Eurogentec (Seraing, Belgium). The PNA oligomer T9/U4/PNA (for sequence, Scheme $1 \mathrm{~A}$; for structure, Scheme $2 \mathrm{~F}$ ) was synthesized and purified by TIB MOLBIOL (Berlin, Germany), and its identity was confirmed by mass spectrometry (PerSeptive Biosystems, Hamburg, Germany). The PS-linked abasic oligomer consists of 19 abasic deoxyribosyl units (dSpacer) and one deoxyguanosyl residue at the 3 '-end (Scheme 1E and Scheme 2E). The latter was used for synthesis because a corresponding dSpacer solid support has not been available. The abasic oligomer was synthesized and HPLC purified by Eurogentec. Heparin was obtained from Sigma Chemical Co. (St. Louis, MO) or from Fluka Chemie AG (Buchs, Switzerland).

Antisense ODNs, chimeric ODNs, and ODNs with uniform backbones (Scheme 1, A, C, D; Scheme 2 A, B, C, D) were synthesized in our laboratory on an Applied Biosystems 391 DNA Synthesizer (PerSeptive Biosystems, Framingham, MA) using 5'-O-cyanoethyl phosphoroamidite chemistry.

The four 3'-(trityl)amino-2' $3^{\prime}$-dideoxynucleoside $5^{\prime}$ $\mathrm{N}, \mathrm{N}$-diisopropyl(2-cyanoethyl) phosphoramidites required for the synthesis of $\mathrm{N}^{\prime} \rightarrow \mathrm{P}^{\prime}$ ' phosphoramidatemodified ODNs were prepared as described (Nelson et al., 1997). 3'-O-(Dimethoxytrityl)-2'-deoxynucleoside 5'-N, N-diisopropyl-(2-cyanoethyl)phosphoramidites, 5'O-(dimethoxytrityl)-2'-O-methyl-ribonucleoside $3^{\prime}-\mathrm{N}, \mathrm{N}-$ diisopropyl(2-cyanoethyl) phosphoramidites, solid supports, and reagents were purchased from Glen Research
(Sterling, VA). In the synthesis cycle, the N3' $\rightarrow$ P5' phosphoramidate-modified oligomers were built in the $5^{\prime}-3^{\prime}$-direction. Coupling time was 20 minutes in the phosphoramidite amine exchange process (Gryaznov and Letzinger, 1999). The resulting internucleotide phosphoramidite was then oxidized to the stable phosphoramidate. Unreacted $3^{\prime}$-amino groups were capped with isobutyric anhydride/ $\mathrm{N}$-methylimidazole. PS linkages were generated by using tetraethylthiuram disulfide as the sulfurization reagent $(\mathrm{Vu}$ and Hirschbein, 1991).

All PAM-modified ODNs were isolated by ion exchange (IE) HPLC on a Shimadzu 10 VA series chromatograph. For analytic IE analysis, a Dionex PA-100 NucleoPac column $(250 \times 4 \mathrm{~mm})$ was used, with a gradient of $0-50 \%$ buffer B vs. buffer A over 45 minutes at a flow rate of $1 \mathrm{ml} / \mathrm{min}$. Buffer A was $0.01 \mathrm{M} \mathrm{NaOH}$, $0.01 \mathrm{M} \mathrm{NaCl}, \mathrm{pH} 12$; buffer B was $0.01 \mathrm{M} \mathrm{NaOH}, 1.5 \mathrm{M}$ $\mathrm{NaCl}, \mathrm{pH}$ 12. Preparative IEC of the oligomers was performed on a Mono Q 10/10 column (Pharmacia, Uppsala, Sweden) with a gradient as described.

The purity of the oligomers was proven by polyacrylamide gel electrophoresis (PAGE) analysis with a Biometra P 25 electrophoresis apparatus. Gels were $20 \%$ acrylamide-bis (ratio 20:1), $0.006 \% \mathrm{w} / \mathrm{v}$ ammonium peroxydisulfate, and $0.06 \% \mathrm{w} / \mathrm{v} \mathrm{N}, \mathrm{N}, \mathrm{N}^{\prime}, \mathrm{N}^{\prime}$-tetramethyl ethylenediamine in $7 \mathrm{M}$ urea and $40 \mathrm{mM}$ Tris-borate, $\mathrm{pH}$ 8.2.

The purified ODNs were analyzed by mass spectrometry on a PE Biosystems Voyager System 4041 STR instrument. As an example, for a PAM-modified ODN with the sequence $5^{\prime}-\mathrm{A}^{+} \mathrm{G}^{+} \mathrm{T}^{+} \mathrm{T}^{+} \mathrm{A}^{+} \mathrm{G}^{+} \mathrm{G}^{+} \mathrm{G}^{+} \mathrm{T}^{+} \mathrm{T}^{+} \mathrm{A}^{+} \mathrm{G}-3^{\prime}$, the molecular weight found by MALDI TOF mass spectrometry was $3728 \mathrm{Da}$, which correlated well with the calculated value of $3729 \mathrm{Da}$. In the case of the chimeric PS-phosphoramidate ODN $5{ }^{\prime}-T^{*} C^{*} A * G * A * T * T * A * G * T * A * C * T *$ $C^{*} G^{*} T^{*} C^{*} A^{*} G^{*} A^{*} T^{+} C^{+} A^{+} G^{+} A^{+} T^{+} A^{+} C^{+} A^{+} G^{+} A-3^{\prime}$ the calculated value was $9838 \mathrm{Da}$, and the molecular weight found by mass spectrometry was $9803 \mathrm{Da}$. Some of the ODNs were analyzed by ${ }^{31} \mathrm{P}-\mathrm{NMR}$. The spectrum of the PS-phosphoramidate chimera with the sequence 5' A*C*T*G*C*T*C*A*G*G*A $\mathrm{A}^{+} \mathrm{G}^{+} \mathrm{T}^{+} \mathrm{T}^{+} \mathrm{A}^{+} \mathrm{G}^{+} \mathrm{G}^{+} \mathrm{G}^{+} \mathrm{T}^{+}{ }_{-}$ $\mathrm{T}^{+} \mathrm{A}^{+} \mathrm{G}-3^{\prime}$ with trimethyl phosphite as internal standard showed the incorporation of 10 PS linkages ( $\delta 53.51-54.44$ $\mathrm{ppm})$ and 11 phosphoramidate linkages $(\delta 5.63-5.91)$. The molecular weight of this chimera found by MALDI TOF mass spectrometry was $6975 \mathrm{Da}$; the calculated value was $6980 \mathrm{Da}$.

\section{Telomerase assay}

Determination of human telomerase activity was based on the TRAP assay (Telomeric Repeat Amplification Protocol; Kim et al., 1994) using a TRAPeze detection kit (Intergen) following a slightly modified protocol. Instead of $50 \mu \mathrm{l}$, we used a $25-\mu \mathrm{l}$ assay volume that contained $20 \mathrm{mM}$ Tris- $\mathrm{HCl}$, pH 8.3, $1.5 \mathrm{mM} \mathrm{MgCl} 2,63 \mathrm{mM}$ 


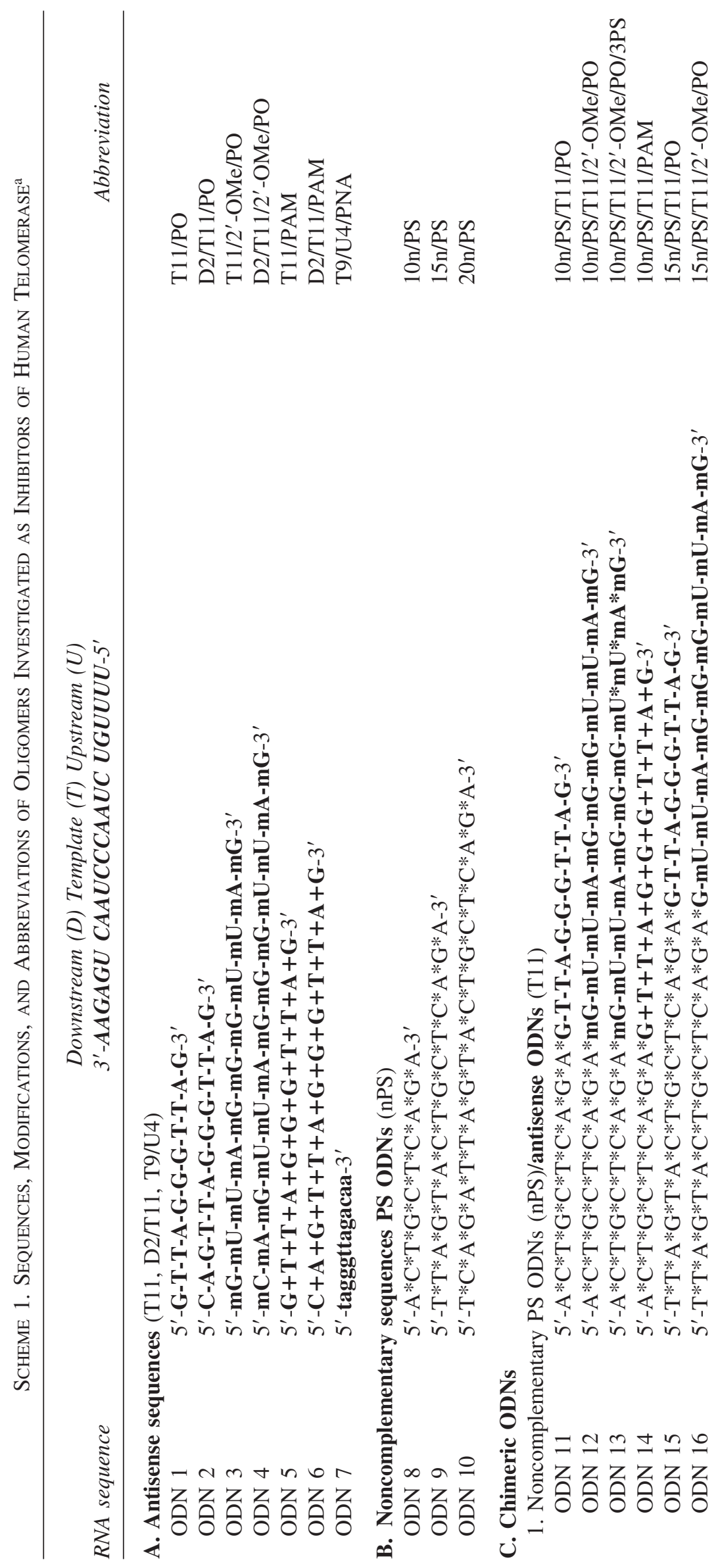




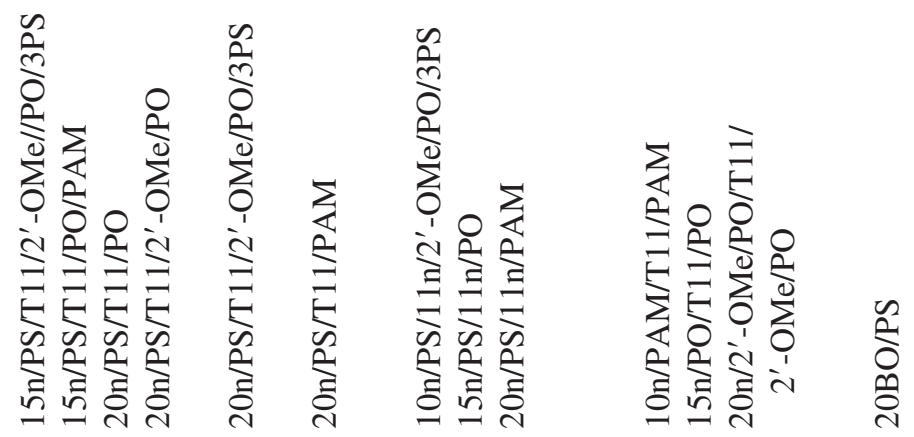

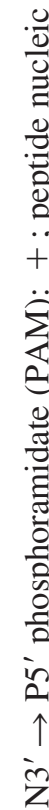

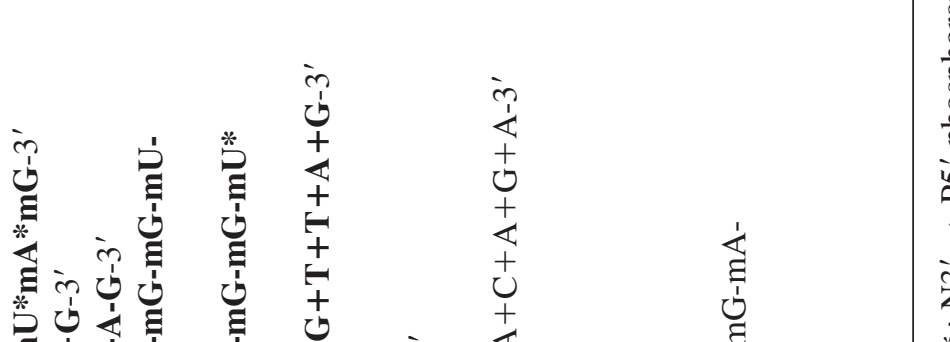

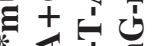

过实

年它它

至

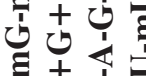

过足

包包

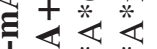

它苍苍

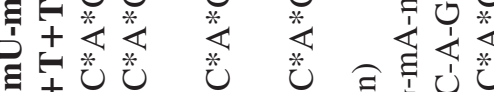

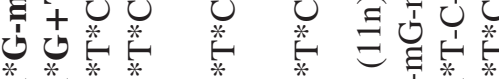

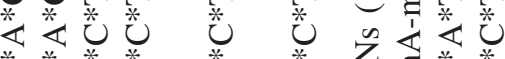

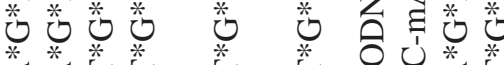

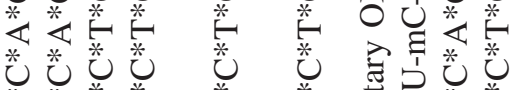

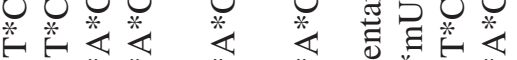

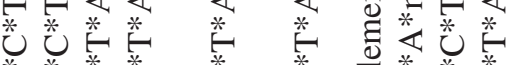

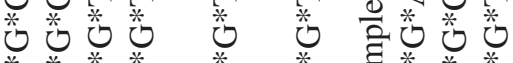

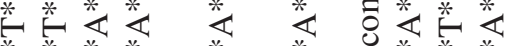

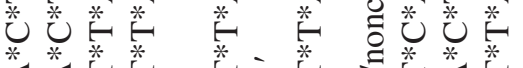

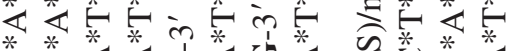

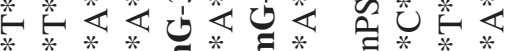

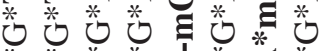

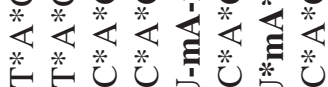

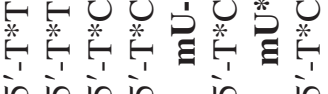

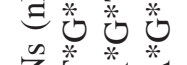

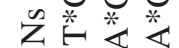

○ิ 获节

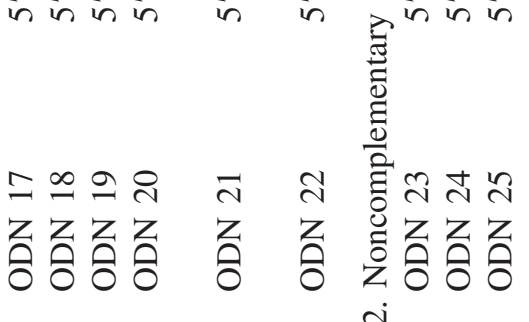

i
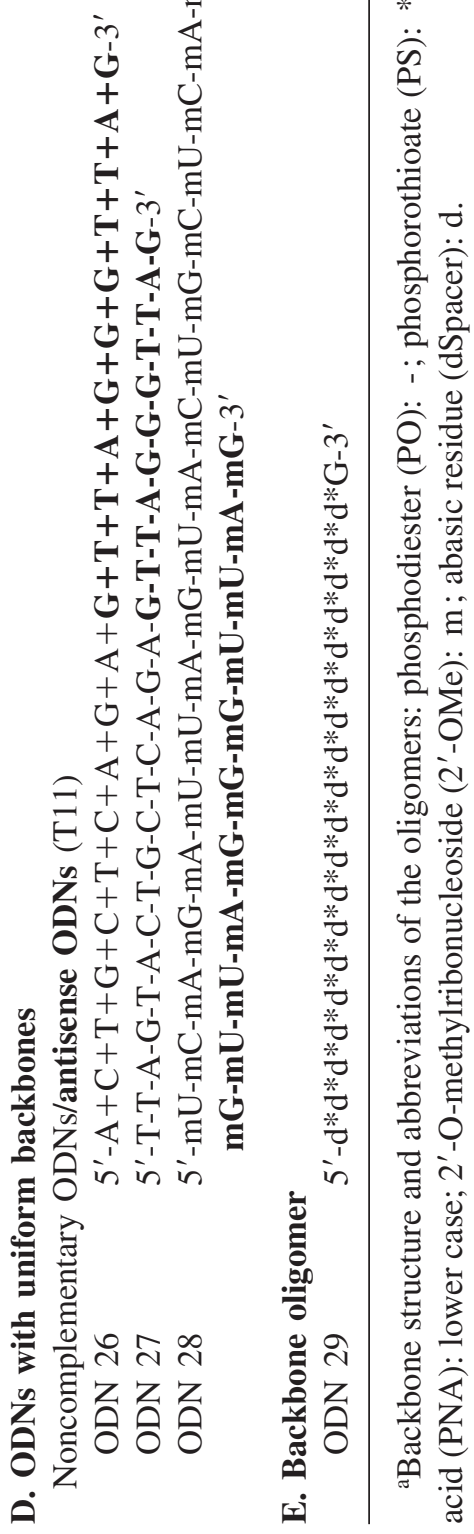

in

莫

*

泀

* 
Scheme 2. Chemical Structures of the Investigated Oligonucleotide Derivatives

A

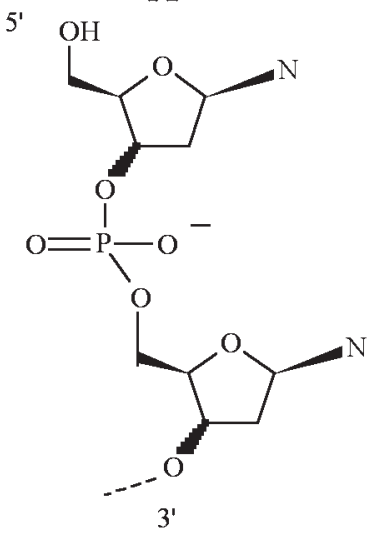

$\mathrm{D}$

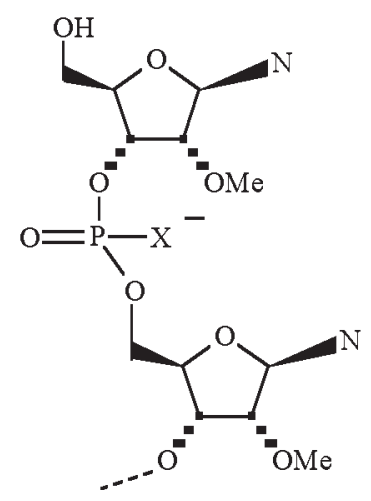

B

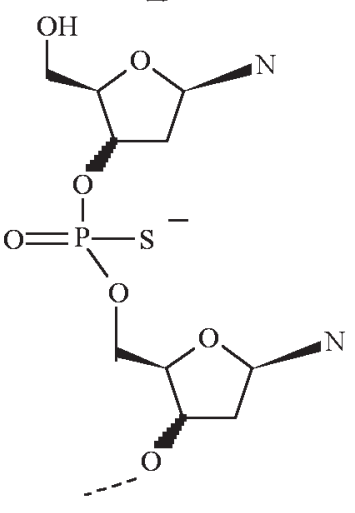

$\mathrm{E}$

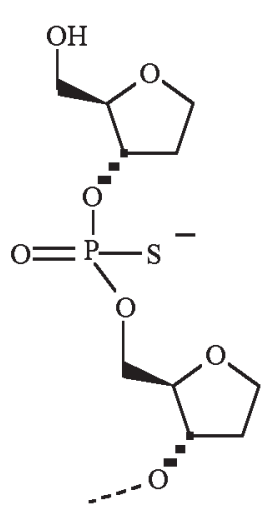

$\mathrm{C}$

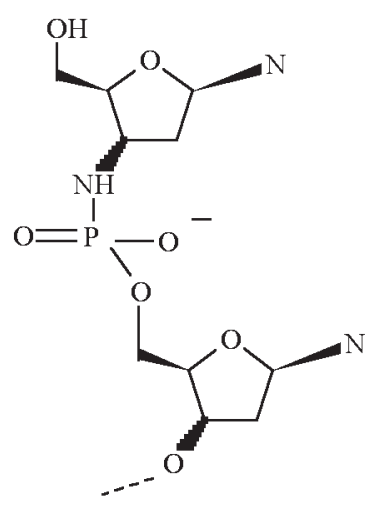

F

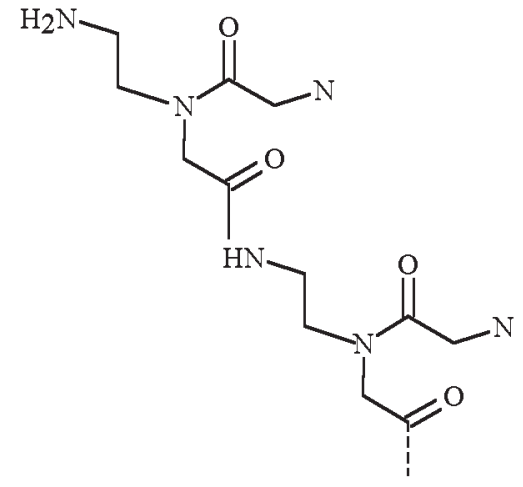

(A) Phospodiester (PO); (B) Phosphorothioate (PS); (C) N3' $\rightarrow$ P5' phosphoroamidate (PAM); (D) 2'-O-methylribonucleoside (2'-OMe; $\mathrm{X}^{-}$is $\mathrm{O}-$ or $\mathrm{S}-$ ); (E) abasic oligomer; (F) peptide nucleic acid (PNA). N, nucleobase.

$\mathrm{KCl}, 0.05 \%$ Tween-20, 1 mM EGTA, $50 \mu \mathrm{M}$ dNTP, $1 \mu \mathrm{l}$ $5^{\prime}{ }^{32} \mathrm{P}$-phosphate-labeled TS primer (5'-AATCCGTCGAGCAGAGTT-3'; final concentration $200 \mathrm{nM}), 0.5 \mu \mathrm{l}$ primer mix, cell extract of U-87 cells (5000 cell equivalent), and the ODN to be tested (Matthes and Lehmann, 1999). The tubes were incubated for 10 minutes at $30^{\circ} \mathrm{C}$, and the reaction products were amplified by PCR and separated on $10 \%$ polyacrylamide gels, followed by quantification with a phosphorimager. Telomerase activity and the percentage of its inhibition by oligomers were calculated as the ratio of intensities of telomerase ladder bands to the intensities of the 36-bp internal standard (Matthes and Lehmann, 1999).

The PNA T9/U4/PNA (for sequence, Scheme 1A) was stored in TE (10 mM Tris-HCl, $1 \mathrm{mM}$ EDTA, $\mathrm{pH}$ 8.0) at $-20^{\circ} \mathrm{C}$, thawed, and heated at $55^{\circ} \mathrm{C}$ for 5 minutes, then kept at ambient temperature for 30 minutes. It was added to the U-87 cell lysates alone or together with another oligomer and preincubated for 30 minutes at $25^{\circ} \mathrm{C}$ and kept on ice until the TRAP assay was completed. The samples were incubated for 30 minutes at $25^{\circ} \mathrm{C}$. The telomerase reaction was stopped by heating at $94^{\circ} \mathrm{C}$ for 5 minutes. PCR was performed at $94^{\circ} \mathrm{C}$ for 45 seconds, $50^{\circ} \mathrm{C}$ for 45 seconds, and $72^{\circ} \mathrm{C}$ for 45 seconds for $25-28$ cycles. The samples were kept for additional 10 minutes at $72^{\circ} \mathrm{C}$, then cooled on ice and subjected to electrophoresis as described.

\section{RESULTS}

\section{Inhibition of telomerase by polyanions}

We have shown that single-stranded and doublestranded PS ODNs inhibit human telomerase in a largely sequence-independent but length-dependent manner. Instead of hybridizing to the RNA template, these ODNs seem to compete effectively with the TS primer for bind- 
ing to the primer binding site of the enzyme (Matthes and Lehmann, 1999).

To demonstrate that the sugar PS backbone and not base recognition is the causative structural element leading to the described effects, we examined an oligomer consisting only of the deoxyribosyl-PS backbone and lacking the nucleic acid bases, except for a single guanine at the $3^{\prime}$-end, which was required for solid-phase synthesis (see Materials and Methods) (Scheme 1E and Scheme 2E). This abasic oligomer with 19 PS linkages (backbone oligomer; 20BO/PS) strongly inhibited telomerase activity, with an $\mathrm{IC}_{50}$ value of $2.3 \mathrm{nM}$ in U-87 cell lysates, which is similar to the value observed for a normal nucleobase-containing 20-mer PS ODN $\left(\mathrm{IC}_{50}=3.3\right.$ $\mathrm{nM}$; for sequence, Scheme 1B).

Then, we investigated the inhibitory activity of the abasic oligomer 20BO/PS in the presence of increasing concentrations of the normal phosphodiester-linked TS primer as described previously (Matthes and Lehmann, 1999). 20BO/PS inhibited telomerase activity competitively with respect to the TS primer, suggesting that both the normal TS primer and the abasic 20BO/PS oligomer are competing for the same binding site (Fig. 1). The binding constant of the TS primer $\left(K_{m}\right)$ was determined to be $8.60 \mathrm{nM}$, and the value for the inhibitory constant $\left(K_{i}\right)$ of the abasic oligomer (20BO/PS) was $1.49 \mathrm{nM}$. The $K_{m} / K_{i}$ ratio indicates an about 3.4-fold higher affinity of the 20BO/PS for the primer binding site than for the TS primer. As the TS primer contains unmodified phosphodiester linkages, the increased affinity of the abasic oligomer may be ascribed to the PS backbone, which affinity may result from the highly increased lipophilicity of the PS linkage.

These results prompted us to investigate heparin as another polyanionic compound having no nucleobases. This sulfated polysaccharide is available only as a mixture of polymers of different chain length, resulting in a broad range of molecular weights. For the most active heparin (Sigma) (MW about 4,000-30,000), the $\mathrm{IC}_{50}$ value was $0.06 \pm 0.01 \mu \mathrm{g} / \mathrm{ml}$. The lower-MW heparins (Fluka) (MW 4,000-6,000; MW 3,000) were less inhibitory $\left(\mathrm{IC}_{50}=0.2-0.8 \mu \mathrm{g} / \mathrm{ml}\right)$. The very strong effect of heparin seems not to be caused by inhibition of the PCR, as amplification of the internal standard was not influenced up to a concentration of $0.2 \mu \mathrm{g} / \mathrm{ml}$ (data not shown).

\section{Additive effects of oligomers binding to telomerase-protein and telomerase-RNA, respectively}

It is conceivable that a combination of drugs targeting two different binding sites on a heteromolecular target, such as telomerase, might produce additive effects. In order to test the hypothesis that PS ODNs and antisense ODNs could target different sites of telomerase and cause

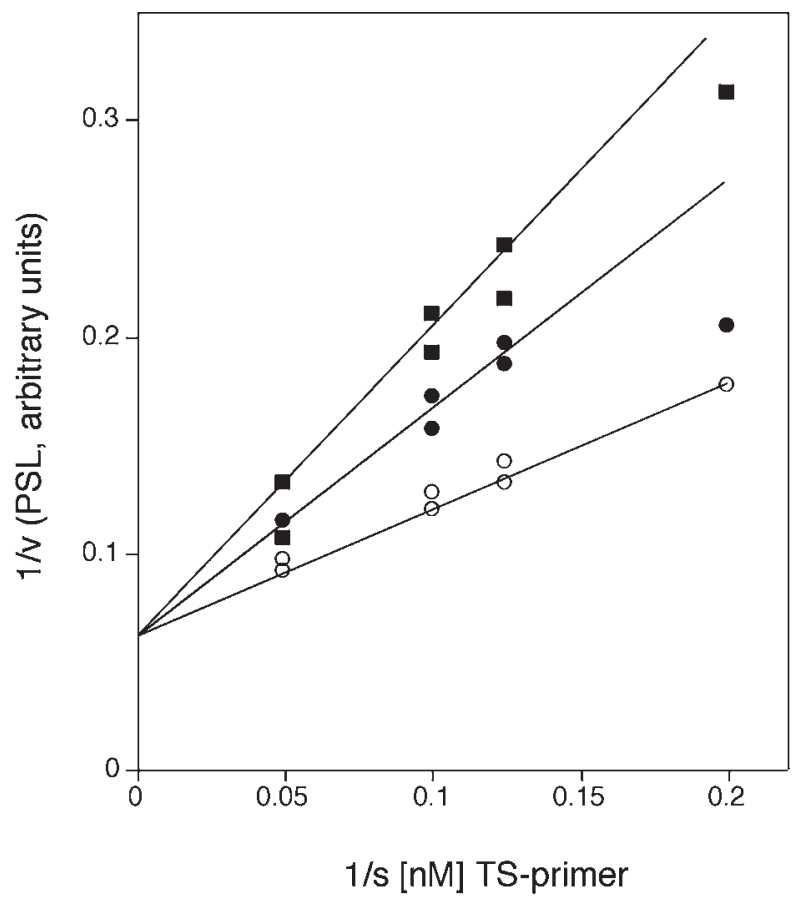

FIG. 1. Kinetics of inhibition of human telomerase by a PSlinked abasic oligomer consisting of 19 abasic deoxyribosyl sugar units and one deoxyguanosyl residue at the 3 '-end (20BO/PS). A double reciprocal plot is shown of TS primer concentration-dependent reaction velocities without inhibitor (open circles) and in the presence of $1.0 \mathrm{nM} 20 \mathrm{BO} / \mathrm{PS}$ (closed circles) and $2.5 \mathrm{nM}$ 20BO/PS (closed squares), respectively. The intensities of the individual lanes were measured as photostimulated luminescence units (PSL) and quantitated as described (Matthes and Lehmann, 1999).

enhanced inhibition, we examined a combination of PS ODNs and antisense ODNs in a TRAP assay with U-87 cell lysates for their efficacy against human telomerase activity.

Figure 2A (left) demonstrates the inhibitory activity of both oligomers alone: $1 \mathrm{nM}$ of a 20-mer PS ODN (20n/PS; for sequence, Scheme 1B) having no complementarity to the RNA template of telomerase and of different concentrations of an unmodified antisense ODN covering 11 bases of the template region (T11) and two adjacent downstream bases (D2) of RNA (termed D2/T11/PO; for sequence, Scheme 1A). Because of the results obtained with an abasic PS ODN analog, the noncomplementary PS ODN was expected to bind to the protein part, and the antisense PO ODN was expected to bind in a sequence-dependent way to the RNA part of telomerase. The $\mathrm{IC}_{50}$ value for $\mathrm{D} 2 / \mathrm{T} 11 / \mathrm{PO}$ antisense ODN was $5.3 \mathrm{nM}$. When administered in combination, their inhibitory activity increased nearly additively (Fig. 2A, right).

The same was true for the abasic oligomer (20BO/PS) when combined with a PNA oligomer complementary to 

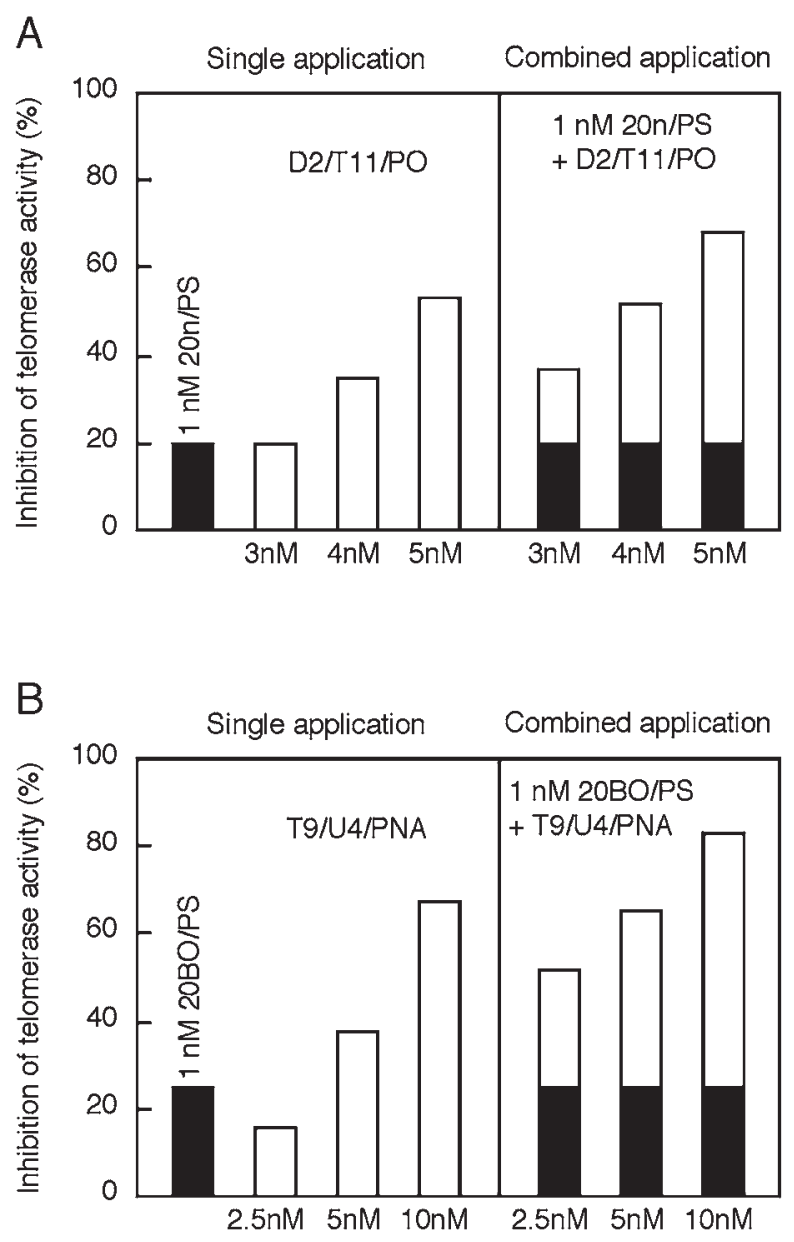

FIG. 2. Effects of two oligomers addressing different targets of telomerase. Inhibitory activity was given for single and combined application: (A) $1 \mathrm{nM} 20 \mathrm{n} / \mathrm{PS}$ and different concentrations of D2/T11/PO; (B) $1 \mathrm{nM}$ 20BO/PS (an abasic sugar-PS backbone oligomer; see Materials and Methods) and different concentrations of T9/U4/PNA. Mean values of at least two different experiments are shown. For sequences, modifications, and abbreviations of the oligomers, see Scheme 1.

nine bases of the RNA template and four adjacent upstream bases (T9/U4/PNA; for sequence, Scheme 1A). As PNA has a neutral backbone, it was not expected to show the nonsequence-dependent protein binding observed for PS ODN and other polyanionic oligomers, such as heparin. This PNA oligomer alone was described previously as the most active inhibitor of human telomerase, with an $\mathrm{IC}_{50}$ of $0.9 \mathrm{nM}$ at $25^{\circ} \mathrm{C}$ (Norton et al., 1996). In our hands, it proved to be less active $\left(\mathrm{IC}_{50}=6.5 \mathrm{nM}\right.$ for HL-60 cell lysates [Matthes and Lehmann, 1999] and $\mathrm{IC}_{50}=6.0 \mathrm{nM}$ for $\mathrm{U}-87$ cell lysates, both at $25^{\circ} \mathrm{C}$ ). The inhibitory activity of T9/U4/PNA was further increased by the addition of $1 \mathrm{nM}$ of the abasic 20BO/PS oligomer (Fig. 2B), suggesting that the neutral PNA and the poly- anionic abasic PS ODN do not compete for the same binding site on telomerase.

\section{Chimeric ODNs as inhibitors of telomerase}

Based on these results, we designed and synthesized chimeric oligomers in which the two active components were linked together to yield a chimeric ODN: the PSmodified ODN for targeting the protein's polyanion binding site and the antisense ODN for targeting the RNA template of telomerase. The PS-modified part consisted of sequences of different length (10-mer, 15-mer, 20-mer) that were unable to bind to the template region of the RNA (10n/PS, 15n/PS, 20n/PS; Scheme 1B). The $3^{\prime}$-parts of the chimeras were either 5'-GTTAGGGTTAG-3', complementary to the 11 bases of the RNA template (indicated by T11), or 5'-TCAGATACAGA-3', noncomplementary to the RNA template (indicated by 11n). The PS ODNs (Scheme 1B) and their extended chimeric counterparts (Scheme 1C.1, C.2) were examined as inhibitors of telomerase activity in U-87 cell lysates. The $\mathrm{IC}_{50}$ values are given in Table 1 . In each case, the $3^{\prime}-$ antisense part increased the efficiency of the pure PS ODNs. The $\mathrm{IC}_{50}$ value of $10 \mathrm{n} / \mathrm{PS}$ decreased from 22.0 $\mathrm{nM}$ to $2.3 \mathrm{nM}$ for the chimeric ODN elongated by 11 antisense bases with natural phosphodiester linkages (10n/PS/T11/PO). Modifications of the antisense part of the chimeric ODNs, aimed to increase the affinity to the RNA (by 2'-OMe/PO, by 2'-OMe/PO/3PS, or by replacement of all PO-internucleotide linkages by PAM [Scheme 1C.1]) did not change their inhibitory effects substantially, despite the known increased binding affinity of 2'-OMe-modified or PAM-modified oligomers to RNA.

Longer PS ODNs alone (15-mer, 20-mer) exhibited better efficacy $\left(\mathrm{IC}_{50}=6.5 \mathrm{nM}\right.$ and $\left.3.3 \mathrm{nM}\right)$ than the shorter 10n/PS ODN. Nevertheless, their 3 '-antisense extensions further increased their inhibitory activity 3.5-8.6-fold (Table 1; $\mathrm{IC}_{50}=0.6-1.0 \mathrm{nM}$ ). Again, the type of modification did not significantly influence their efficiency. Figure 3 shows an example of the concentration-dependent effects of 15n/PS/T11/PAM in comparison to $15 \mathrm{n} / \mathrm{PS}$ on telomerase activity in the TRAP assay. When the antisense sequence of the chimeric ODNs was replaced by a noncomplementary sequence (Scheme 1C.2), the inhibitory effect caused by the antisense part was abolished almost completely (Table 1, italics).

As additional controls to the chimeric ODNs (21-mer, 26-mer, and 31-mer), we examined oligomers of the same length and sequence but with uniform backbones (Scheme 1D). The $\mathrm{IC}_{50}$ values were $287 \mathrm{nM}$ for a 21 -mer PAM-modified ODN (10n/PAM/T11/PAM), $21.4 \mathrm{nM}$ for an unmodified 26-mer ODN (15n/PO/T11/PO), and $34 \mathrm{nM}$ for a 31-mer 2'-OMe-modified ODN (20n/ $\left.2^{\prime}-\mathrm{OMe} / \mathrm{PO} / \mathrm{T} 11 / 2^{\prime}-\mathrm{OMe} / \mathrm{PO}\right)$. We further compared the 
Table 1. $\mathrm{IC}_{50}$ Values (nM) For Inhibition of Telomerase Activity in U-87 Cell Lysates ${ }^{\mathrm{a}}$

\begin{tabular}{|c|c|c|c|c|c|}
\hline \multirow{3}{*}{$\begin{array}{c}\text { Abbreviations } \\
\text { of ODNs }\end{array}$} & \multicolumn{5}{|c|}{$I C_{50}, n M^{\mathrm{b}}$} \\
\hline & \multirow[b]{2}{*}{$P S-O D N s$} & \multicolumn{4}{|c|}{ Backbone structure of the $3^{\prime}$-extensions of PS-ODNs } \\
\hline & & $/ P O$ & $/ 2^{\prime}-O M e / P O$ & $/ 2^{\prime} \mathrm{OMe} / \mathrm{PO} / 3 \mathrm{PS}$ & $/ P A M$ \\
\hline 10n/PS & 22.0 & & & & \\
\hline 10n/PS/T11 & & 2.3 & 2.0 & 1.8 & 5.0 \\
\hline $10 n / P S / 11 n$ & & 24.3 & 16.9 & 15.2 & 26.0 \\
\hline 15n/PS & 6.5 & & & & \\
\hline 15n/PS/T11 & & 1.0 & 0.80 & 0.76 & 0.90 \\
\hline $15 n / P S / 11 n$ & & 3.9 & 5.3 & 4.6 & 7.4 \\
\hline 20n/PS & 3.3 & & & & \\
\hline 20n/PS/T11 & & $\mathbf{N D}^{\mathbf{c}}$ & 0.85 & 0.60 & 0.95 \\
\hline $20 n / P S / 11 n$ & & 2.4 & 2.8 & 3.0 & 3.4 \\
\hline
\end{tabular}

'Inhibition by mismatched PS ODNs of different length in comparison to such extended at the 3'-end with unmodified/modified antisense oligomers complementary to 11 bases of RNA template (T11) or noncomplementary to the template region (11n). For sequences and modifications, see Scheme 1.

${ }^{\mathrm{b}} \mathrm{IC}_{50}$ values were mean values of three independent experiments.

${ }^{\mathrm{c} N D}$, not detectable, interference with PCR.

chimeric ODNs with antisense ODNs covering either 11 bases of the RNA template alone (T11) or 2 additional downstream bases (D2/T11) in an unmodified/modified form that were considered the most effective ODNs (Pitts and Corey, 1998; Herbert et al., 1999, 2002). Their $\mathrm{IC}_{50}$ values (Table 2) demonstrate that they were less efficient than the comparable chimeric ODNs (Table 1). The only exception is the unmodified antisense ODN D2/T11/PO $\left(\mathrm{IC}_{50}=5.3 \mathrm{nM}\right)$, which was found to be equally active as the chimeric ODN $10 \mathrm{n} / \mathrm{PS} / \mathrm{T} 11 / \mathrm{PAM}\left(\mathrm{IC}_{50}=5.0 \mathrm{nM}\right)$.

\section{Inhibition by chimeric ODNs of telomerase activity in $U-87$ cells}

We examined at the cellular level if chimeric ODNs, compared with PS ODNs and some antisense ODNs, were capable of suppressing telomerase activity 20 hours after transfection with ODN-lipofectin complexes. For this, U-87 cells proved to be most appropriate, as shown by the high uptake of a $5^{\prime}$-FITC-labeled chimeric ODN (20n/PS/T11/2'-OMe/PO) into nuclei of U-87 cells 4 hours after transfection with lipofectin (data not shown).

The 10n/PS oligomer alone and its chimeric counterpart extended by an 11-mer unmodified antisense part were nearly inactive at the cellular level $\left(\mathrm{ID}_{50}>2.25\right.$ $\mu \mathrm{M})$ (Table 3). The same was true for all T11 antisense ODNs (Table 2) (T11/PO, T11/2'-OMe/PO, and T11/ PAM; $\left.\mathrm{ID}_{50} \geqq 2.0 \mu \mathrm{M}\right)$ and $\mathrm{D} 2 / \mathrm{T} 11$ antisense ODNs (D2/T11/PO, $\quad \mathrm{ID}_{50}>2.0 \mu \mathrm{M} ; \quad \mathrm{D} 2 / \mathrm{T} 11 / 2^{\prime}-\mathrm{OMe} / \mathrm{PO}$, $\mathrm{ID}_{50}=1.2 \mu \mathrm{M}$; D2/T11/PAM, $\left.\mathrm{ID}_{50}=2.0 \mu \mathrm{M}\right)$. In contrast, extensions of the 10n/PS ODN by modified anti- sense oligomers increased strongly its intracellular inhibitory effect $\left(\mathrm{ID}_{50}=0.49-0.70 \mu \mathrm{M}\right)$ (Table 3$)$. The same effects were found with antisense extensions of the $15 \mathrm{n} / \mathrm{PS}$ and $20 \mathrm{n} / \mathrm{PS}$ ODNs, which alone gave $\mathrm{ID}_{50}$ values of $>2.25 \mu \mathrm{M}$ and $0.40 \mu \mathrm{M}$, respectively. The modified antisense extensions (T11) of the 15n/PS ODNs showed $\mathrm{ID}_{50}$ values between 0.35 and $0.60 \mu \mathrm{M}$. For the $20 \mathrm{n} / \mathrm{PS}$, extended by the modified antisense sequence, we found $\mathrm{ID}_{50}$ values between 0.04 and $0.08 \mu \mathrm{M}$.

The most effective chimeric ODNs were 20n/PS/T11/ PAM $\left(\mathrm{ID}_{50}=0.04 \mu \mathrm{M}\right)$, containing the complete phosphoramidate substitution in the antisense part, and the $20 \mathrm{n} / \mathrm{PS} / \mathrm{T} 11 / 2^{\prime}-\mathrm{OMe} / 3 \mathrm{PS}\left(\mathrm{ID}_{50}=0.06 \mu \mathrm{M}\right)$, which was completely 2 '-O-methyl modified in the antisense part and carried three PS linkages at the 3 '-end. Without lipofectin, however, these ODNs were almost inactive $\left(\mathrm{ID}_{50}>2 \mu \mathrm{M}\right)$. Replacement of the antisense sequence (T11) of the chimeric ODNs by a noncomplementary one (11n) reduced the effects to nearly that observed for the PS ODNs (Table 3, italics).

\section{DISCUSSION}

Besides their sequence-dependent antisense effects, PS ODNs display additional effects that appear to be caused mainly by sequence-independent interactions with proteins. Such PS ODN-protein complexes can be formed particularly with proteins binding negatively charged glycosaminoglycans, such as heparin. 
A

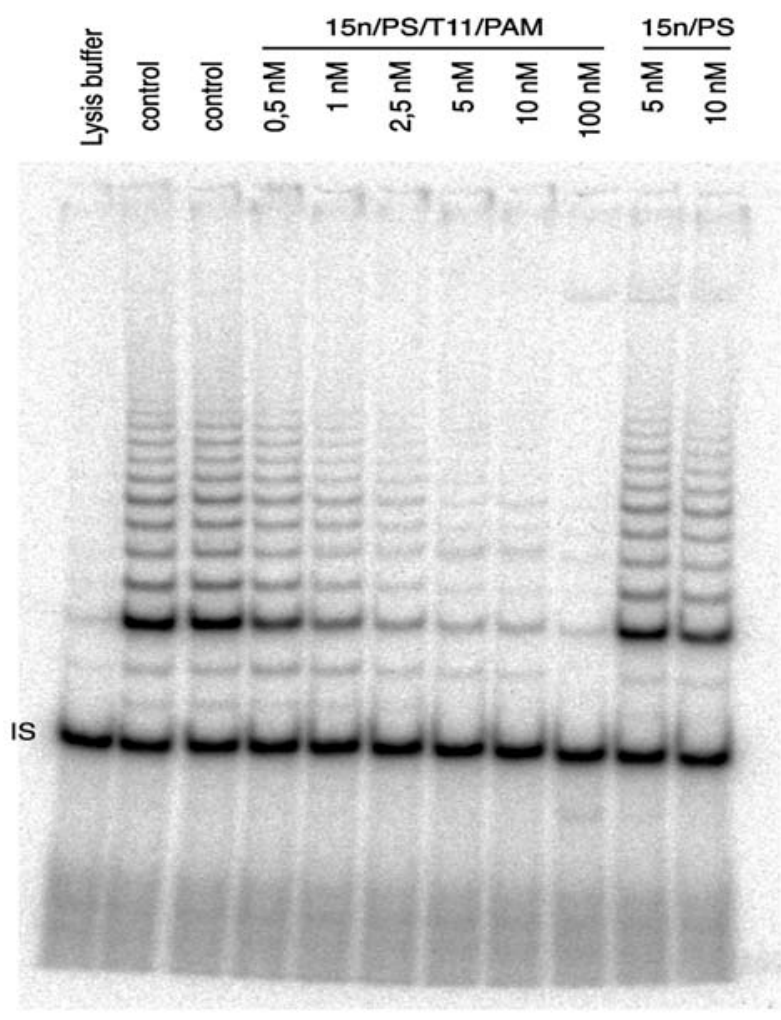

B

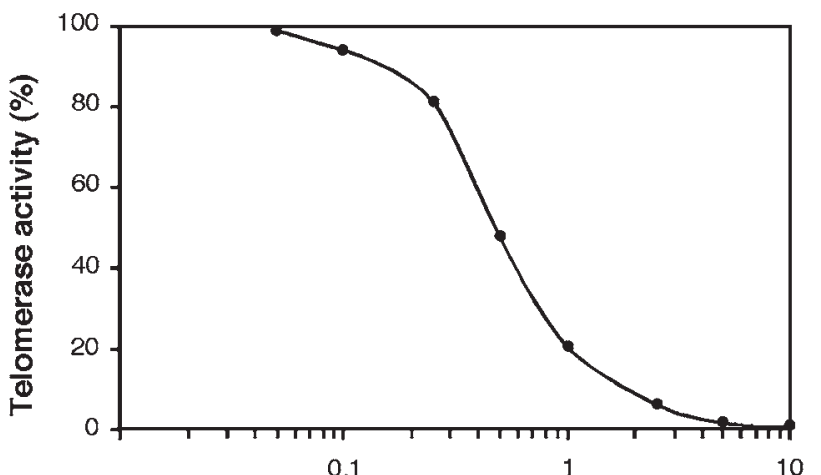

Concentrations of $15 \mathrm{n} / \mathrm{PS} / \mathrm{T1} 1 / \mathrm{PAM}$ (nM)

FIG. 3. Inhibitory effects of $15 \mathrm{n} / \mathrm{PS} / \mathrm{T} 11 / \mathrm{PAM}$ in comparison to $15 \mathrm{n} / \mathrm{PS}$ on telomerase activity from U-87 cell lysates. (A) TRAP gel showing telomerase products after addition of different concentrations of $15 \mathrm{n} / \mathrm{PS} / \mathrm{T} 11 / \mathrm{PAM}$ or $15 \mathrm{n} / \mathrm{PS}$. The location of the internal standard (IS) is indicated. The Lysis buffer lane represents a negative control containing no cell extract. The control lanes represent the positive controls without ODNs for $100 \%$ telomerase activity. (B) Concentration-dependent inhibition of telomerase activity by $15 \mathrm{n} / \mathrm{PS} / \mathrm{T} 11 / \mathrm{PAM}$ calculated from the phosphorimaged lanes in (A), as described (Matthes and Lehmann, 1999).

Examples of heparin-binding proteins and receptors are basic fibroblast growth factor (bFGF), platelet-derived growth factor (PGDF), vascular endothelial growth factor (VEGF) and its receptor, and the epidermal growth factor receptor (EGFR) (Stein, 1996; Stein, 1997). These proteins are able to bind PS ODNs with high affinity, which might influence their function (Rockwell et al., 1997). Similarly, such enzymes as HIV-RT or its associated RNase $\mathrm{H}$ can be inhibited by PS ODNs in a widely sequence-independent manner (Majumder et al., 1989; Cheng et al., 1991). Human telomerase appears to be a further example of a heparin-binding protein that is inhibited very strongly by PS ODNs in a largely sequenceindependent manner (Norton et al., 1996; Matthes and Lehmann, 1999). We assume a competitive interaction of PS ODNs with the primer at the primer binding site of telomerase protein (Matthes and Lehmann, 1999).

Here, we report on further findings supporting the model that polyanionic structures of PS ODNs alone are sufficient for the described effects. Thus, an oligomer consisting of 20 deoxyribosyl units linked via PS groups but lacking nucleobases (except one at the 3 '-end) was sufficient to give the full inhibitory activity (abasic oligomer) $\left(20 \mathrm{BO} / \mathrm{PS}, \mathrm{IC}_{50}=2.3 \mathrm{nM}\right)$ of a 20 -mer PS ODN in U-87 cell lysates (20n/PS-ODN, $\mathrm{IC}_{50}=3.3$ $\mathrm{nM}$ ). We have demonstrated that the abasic oligomer 20BO/PS inhibited telomerase activity competitively with respect to TS primer. This effect was comparable to that described earlier for 20n/PS-ODN (Matthes and Lehmann, 1999). The binding constant of the TS primer $\left(K_{m}\right)$ was determined to be $8.60 \mathrm{nM}$, and the $K_{i}$ value was $1.49 \mathrm{nM}$. Thus, the $K_{m} / K_{i}$ ratio indicates an approximately 3.4-fold higher affinity of the 20BO/PS for the primer binding site than the TS primer. Furthermore, we have shown that heparin (MW about 4,000-30,000) inhibited telomerase activity with similar efficiency to HIV-RNase $\mathrm{H}\left(\mathrm{IC}_{50}=0.06 \mu \mathrm{g} / \mathrm{ml}\right.$ ) (Moelling et al., 1989). The specific binding site of heparin at the telomerase remains to be elucidated, however.

\section{TABle 2. CONCENTRATions of Antisense ODNS} REQUIRED FOR 50\% INHIBITION OF TELOMERASE Activity in Lysates and in Intact U-87 Cells ${ }^{\mathrm{a}}$

\begin{tabular}{lcc}
\hline $\begin{array}{l}\text { Abbreviations } \\
\text { of } O D N s\end{array}$ & $\begin{array}{c}U-87 \text { cell lysates } \\
I C_{50}, n^{\mathrm{b}}\end{array}$ & $\begin{array}{c}U-87 \text { cells } \\
I D_{50}, \mu M^{\mathrm{b}}\end{array}$ \\
\hline T11/PO & 35.0 & $>2.0$ \\
D2/T11/PO & 5.3 & $>2.0$ \\
T11/2'-OMe/PO & 43 & 2.0 \\
D2/T11/2'-OMe/PO & 42 & 1.2 \\
T11/PAM & 472 & $>2.0$ \\
D2/T11/PAM & 167 & 2.0 \\
\hline
\end{tabular}

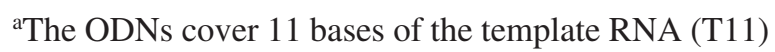
or additionally 2 adjacent downstream bases (D2/T11). For sequences and modifications, see Scheme 1.

${ }^{b} \mathrm{IC}_{50}$ and $\mathrm{ID}_{50}$ values were mean values of three independent experiments. 
Table 3. ID $_{50}$ Values $(\mu \mathrm{M})$ For Inhibition of Telomerase Activity in U-87 Cells 20 Hours After Transfection with ODN-LiPOFECTIN COMPLEXES ${ }^{\mathrm{a}}$

\begin{tabular}{|c|c|c|c|c|c|}
\hline \multirow{3}{*}{$\begin{array}{l}\text { Abbreviations } \\
\text { Of ODNs }\end{array}$} & \multicolumn{5}{|c|}{$I D_{50}, \mu M^{\mathrm{b}}$} \\
\hline & \multirow[b]{2}{*}{ PS ODNs } & \multicolumn{4}{|c|}{ Backbone structure of the $3^{\prime}$-extensions of PS-ODNs } \\
\hline & & $/ P O$ & $/ 2^{\prime}-\mathrm{OMe} / \mathrm{PO}$ & $/ 2^{\prime}-O M e / P O / 3 P S$ & /PAM \\
\hline 10n/PS & $>2.25^{\mathrm{c}}$ & & & & \\
\hline 10n/PS/T11 & & $>2.25$ & 0.70 & 0.51 & 0.49 \\
\hline $10 n / P S / 11 n$ & & $>2.25$ & $>1.25$ & $>1.25$ & $>2.25$ \\
\hline 15n/PS & $>2.25$ & & & & \\
\hline 15n/PS/T11 & & 0.71 & 0.60 & 0.35 & 0.37 \\
\hline $15 n / P S / 11 n$ & & $>1.25$ & $>1.25$ & $>1.25$ & $>1.25$ \\
\hline 20n/PS & 0.40 & & & & \\
\hline 20n/PS/T11 & & 0.26 & 0.08 & 0.06 & 0.04 \\
\hline $20 n / P S / 11 n$ & & 0.61 & 0.30 & 0.45 & 0.97 \\
\hline
\end{tabular}

aMismatched PS-ODNs of different lengths, were compared with such extended at the 3 '-end with unmodified/ modified antisense oligomers complementary to 11 bases of RNA template (T11) or noncomplementary to the template region (11n). For sequences and modifications, see Scheme 1.

${ }^{\mathrm{b}} \mathrm{ID}_{50}$ values were mean values of three independent experiments.

c> means $21 \%-39 \%$ inhibition at given concentration.

The sequence-independent effects of PS ODNs on some proteins are often considered as being disadvantageous for the application of PS ODNs as antisense therapeutics. In the case of telomerase, however, the close neighborhood of the RNA template and the PS ODN binding site of the protein did allow the design of a new type of chimeric ODN combining the high affinity to both the protein site and the RNA template site of telomerase. Such chimeric ODNs appear to take advantage of the very high, although mainly sequence-independent, affinity of PS ODNs against telomerase protein, as selectivity can be provided by an antisense extension at the $3^{\prime}$ end of these PS ODNs that is targeted to the RNA part of telomerase.

Prior to the synthesis and investigation of such chimeric ODNs, we tested a combination of two individual oligomers targeting both sites of telomerase. We could demonstrate that such combinations showed increased inhibitory activity compared with the single oligomers. This was true for the 20-mer PS ODN (20n/PS) and the 20-mer sugar PS abasic oligomer (20BO/PS). Their inhibitory efficacy in U-87 cell lysates increased in a nearly additive manner when combined with the antisense oligomers D2/T11/PO and T9/U4/PNA, respectively.

These results prompted us to synthesize chimeric PS oligomers of variable length (10-mer, 15-mer, 20-mer), which were extended at the $3^{\prime}$-end by antisense oligomers with different modifications covering 11 bases of the template. Our data demonstrate that the inhibitory effects of all the PS ODNs (10-mer, 15-mer, and 20-mer) can be increased by the antisense ODN extensions. The largest additional effect was found for the 10-mer PS ODN (up to 12.2-fold) followed by the 15-mer PS ODN (up to 8.6-fold), and was lowest for the 20-mer PS ODN (up to 5.5-fold). The structural modifications of the antisense part (2'-OMe, PAM) of the chimeric ODNs had virtually no influence on their efficacy during the $10 \mathrm{~min}$ utes of incubation of the U-87 cell lysates.

Although the contribution of the antisense part to the inhibitory effect diminished with increasing length of the PS ODNs in all cases, it was much higher than expected by simple addition of the individual effects. Investigation of a series of controls indicated that the antisense sequence as well as the PS part both contribute to the potent inhibitory activity of the chimeric ODNs.

1. Changing the complementary sequence of the antisense part to a noncomplementary one resulted in chimeric ODNs that showed inhibitory activity comparable to pure PS ODNs (10-mer, 15-mer, 20-mer) (Table 1, italics).

2. ODNs of the same length (21-mer, 26-mer, 31-mer) and sequence as the chimeric ODNs but characterized by uniform backbone structures in both parts of the ODNs (e.g., 21-mer PAM, 26-mer PO, 31-mer 2'-OMe/PO) displayed much less inhibitory activity, demonstrating that the length of the ODNs with uniformly unmodified/modified backbone structures is not responsible for the described effects of the chimeric ODNs.

3. In comparison, nearly all simple antisense ODNs (un- 
modified/modified as the antisense part of the chimeric ones) targeting the 11 bases of RNA template of telomerase (T11) and 2 additional downstream bases (D2/T11), respectively, were less active than the chimeric ODNs.

The results with these control ODN variants suggest that both the antisense sequence and the PS part are required for the described effects of chimeric ODNs. Following our strategy, Tarkanyi et al. (2005) found that chimeric ODNs in which 4-thiouridylate oligomers instead of PS ODNs were used for binding to the protein site of telomerase strengthen the inhibitory activity of simple antisense ODNs in dependence on the length of the 4thiouridylate part.

Antisense ODNs with a PAM-modified backbone have been described as excellent antisense oligomers with increased affinity and specificity for various RNA targets and a high nuclease stability (Gryaznov, 1999). Surprisingly, PAM-modified antisense ODNs targeting the RNA template of telomerase proved to be less active than all other antisense ODNs in our U-87 cell lysates (e.g., T11/PAM, $\mathrm{IC}_{50}=472 \mathrm{nM}$; and D2/T11/PAM, $\left.\mathrm{IC}_{50}=167 \mathrm{nM}\right)($ Table 2). This finding is unexpected, as the previously described PAM-modified antisense ODNs (corresponding to D2/T11 and T9/U4) showed high binding affinity to complementary RNA in vitro and potent antisense inhibition in intact cells, although direct inhibitory effects on telomerase activity in vitro have not been described (Herbert et al., 2002). In contrast, when PAM-modified ODNs were linked to the PS ODNs (10-mer, 15-mer, 20-mer), the resulting chimeric ODNs proved to be very powerful inhibitors of telomerase activity in $\mathrm{U}-87$ cell lysates $\left(\mathrm{IC}_{50}=5.0 \mathrm{nM}, 0.90 \mathrm{nM}\right.$, $0.95 \mathrm{nM})$.

Although we cannot provide direct evidence for our model, we hypothesize that binding of the PS part to the primer binding site might increase the accessibility of the RNA template to the antisense part of chimeric ODNs.

The most effective oligomers in this study were 20n/PS/T11/2' ${ }^{\prime} \mathrm{OMe} / \mathrm{PO} / 3 \mathrm{PS}, 15 \mathrm{n} / \mathrm{PS} / \mathrm{T} 11 / 2^{\prime}{ }^{-} \mathrm{OMe} / \mathrm{PO} /$ $3 \mathrm{PS}$, and $15 \mathrm{n} / \mathrm{PS} / \mathrm{T} 11 / 2^{\prime}-\mathrm{OMe} / \mathrm{PO}$ with $\mathrm{IC}_{50}$ values of $0.60-0.80 \mathrm{nM}$ (Table 1). This ranking of telomerase inhibition changed when chimeric ODNs were delivered in U-87 cells by ODN-lipofectin complexes. This might be caused by differences in cellular uptake, intracellular stability against nucleases, and length and target accessibility of the chimeric ODNs. Pure 10n/PS and 15n/PS oligomers proved to be nearly inactive, whereas 20n/PS gave an $\mathrm{ID}_{50}$ value of $0.40 \mu \mathrm{M}$ when exposed for 20 hours. The antisense extensions increased the efficiency of the PS ODNs also in the cellular assay, here, however, in dependence on the kind of modification.

Chimeric ODNs with an antisense sequence carrying the 2'-OMe modification and phosphodiester linkages at the $3^{\prime}$-end proved to be less potent at the cellular level than those chimeras with three terminal PS or PAMmodified antisense parts. The enhanced activity is likely caused by the higher nuclease stability of the latter (Gryaznov, 1999; Peymann and Uhlmann, 1996). The 20-mer PS ODN extended by nuclease-stable antisense oligomers showed the most potent inhibition of telomerase at the cellular level 20 hours after exposure $(20 \mathrm{n} /$ $\mathrm{PS} / \mathrm{T} 11 / \mathrm{PAM}, \mathrm{ID}_{50}=0.04 \mu \mathrm{M} ; 20 \mathrm{n} / \mathrm{PS} / \mathrm{T} 11 / 2^{\prime} \mathrm{OMe} / \mathrm{PO} /$ $3 \mathrm{PS}, \mathrm{ID}_{50}=0.06 \mu \mathrm{M} ; 20 \mathrm{n} / \mathrm{PS} / \mathrm{T} 11 / 2^{\prime}-\mathrm{OMe} / \mathrm{PO}, \mathrm{ID}_{50}=$ $0.08 \mu \mathrm{M}$, against $\mathrm{ID}_{50}=0.40 \mu \mathrm{M}$ for $20 \mathrm{n} / \mathrm{PS}$ alone) (Table 3). Changing the complementary sequence of the antisense part to a noncomplementary part resulted in chimeric ODNs that were active only in the range of pure PS ODNs (10-mer, 15-mer, 20-mer) (Table 3, italics), thus underlining the essential influence of the antisense part on the activity of the chimeric ODNs at the cellular level.

It is important to note that in contrast to the chimeric ODNs, pure antisense ODNs, directed to telomerase RNA (T11, D2/T11, unmodified or modified) (Table 2), showed at the cellular level $\mathrm{ID}_{50}$ values as high as $1.2 \mathrm{up}$ to $>2 \mu \mathrm{M}$. In comparison, $\mathrm{ID}_{50}$ values of about $0.5-1$ $\mu \mathrm{M}$ for inhibition of telomerase activity in immortalized human breast cells after 24 hours incubation with PAMmodifed ODNs (corresponding to T11 and T9/U4, respectively) were described recently (Herbert et al., 2002).

In conclusion, the superior activity of the novel chimeric ODNs targeting two different sites of telomerase compared with simple antisense ODNs makes them attractive candidates for more detailed studies of inhibiting tumor growth.

\section{ACKNOWLEDGMENT}

E. M. is grateful to the Deutsche Forschungsgemeinschaft for support of these studies (grant Ma 1630/3-1).

\section{REFERENCES}

AUTEXIER, C. (1999). Telomerase as a possible target for anticancer therapy. Chem. Biol. 6, R299-R303.

CHENG, Y.-C., GAO, W.-Y., and HAN, F.-S. (1991). Phosphorothioate oligonucleotides as potential antiviral compounds against human immunodeficiency virus and herpes viruses. Nucleosides Nucleotides 10, 155-166.

COUNTER, C.M., MEYERSON, M., EATON, E.N., and WEINBERG, R.A. (1997). The catalytic subunit of yeast telomerase. Proc. Natl. Acad. Sci. USA 94, 9202-9207.

ELAYADI, A.N., BRAASCH, D.A., and COREY, D.R. (2002). Implications of high-affinity hybridization by locked nucleic acid oligomers for inhibition of human telomerase. Biochemistry 41, 9973-9981. 
ELAYADI, A.N., DEMIEVILLE, A., WANCEWICZ, E.V., MONIA, B.P., and COREY, D.R. (2001). Inhibition of telomerase by 2'-O-(2-methoxyethyl) RNA oligomers: Effects of length, phosphorothioate substitution and time inside cells. Nucleic Acids Res. 29, 1683-1689.

FENG, J., FUNK, W.D., WANG, S.-S., WEINREICH, S.L., AVILION, A.A., CHIU, C.-P., ADAMS, R.R., CHANG, E., ALLSOPP, R.C., YU, J., LE, S., WEST, M.D., HARLEY, C.B., ANDREWS, W.H., GREIDER, C.W., and VILLEPONTEAU, B. (1995). The RNA component of human telomerase. Science 269, 1236-1241.

GLUKHOV, A.I., ZIMNIK., O.V., GORDEEV, S.A., and SEVERIN, S.E. (1998). Inhibition of telomerase activity of melanoma cells in vitro by antisense oligonucleotides. Biochem. Biophys. Res. Commun. 248, 368-371.

GRYAZNOV, S.M. (1999). Oligonucleotide N3' $\rightarrow$ P5' phosphoramidates as potential therapeutic agents. Biochim. Biophys. Acta 1489, 131-140.

GRYAZNOV, S.M., and LETZINGER, R.L. (1999). Synthesis and properties of oligonucleotides containing aminodeoxythymidine units. Nucleic Acids Res. 22, 3403-3409.

HAHN, W.C., STEWART, S.A., BROOKS, M.W., YORK, S.G., EATON, E., KURACHI, A., BEIJERSBERGEN, R.L., KNOLL, J.H.M., MEYERSON, M., and WEINBERG, R.A. (1999). Inhibition of telomerase limits the growth of human cancer cells. Nature Med. 5, 1164-1170.

HAMILTON, S.E., SIMMONS, C.G., KATHIRIYA, I.S., and COREY, D.R. (1999). Cellular delivery of peptide nucleic acids and inhibition of human telomerase. Chem. Biol. 6, 343-351.

HAMMOND, P.W., LIVELY, T.N., and Cech, T.R. (1997). The anchor site of telomerase from Euplotes adiculatus revealed by photo-cross-linking to single- and double-stranded DNA primers. Mol. Cell. Biol. 17, 296-308.

HARRISON, J.G., FRIER, C., LAURANT, R., DENNIS, R., RANEY, K.D., and BALASUBRAMANIAN, S. (1999). Inhibition of human telomerase by PNA-cationic peptide conjugates. Bioorg. Med. Chem. Lett. 9, 1273-1278.

HERBERT, B.-S., PITTS, A.E., BAKER, S.I., HAMILTON, S.E., WRIGHT, W.E., SHAY, J.W., and COREY, D.R. (1999). Inhibition of human telomerase in immortal human cells leads to progressive telomere shortening and cell death. Proc. Natl. Acad. Sci. USA 96, 14276-14281.

HERBERT, B.-S., PONGRACZ, K., SHAY, J.W., and GRYAZNOV, S.M. (2002). Oligonucleotide N3' $\rightarrow$ P5' $^{\prime}$ phosphoramidates as efficient telomerase inhibitors. Oncogene 21, 638-642.

KANAZAWA, Y., OHKAWA, K., UEDA, K., MITA, E., TAKEHARA, T., SASAKI, Y., KASAHARA, A., and HAYASHI, N. (1996). Hammerhead ribozyme-mediated inhibition of telomerase activity in extracts of human hepatocellular carcinoma cells. Biochem. Biophys. Res. Commun. 225, 570-576.

KIM, N.W., PIATYSZEK, M.A., PROWSE, K.R., HARLEY, C.B., WEST, M.D., HO, P.L.C., COVIELLO, G.M., WRIGHT, W.E.,WEINRICH, S.L., and SHAY, J.W. (1994). Specific association of human telomerase activity with immortal cells and cancer. Science 266, 2011-2015.

KONDO, S., KONDO, Y., LI, G., SILVERMAN, R.H., and COWELL, J.K. (1998). Targeted therapy of human malig- nant glioma in a mouse model by 2-5 A antisense directed against telomerase RNA. Oncogene 16, 3323-3330.

KONDO, Y., KOMATA, T., and KONDO, S. (2001). Combination therapy of 2-5A antisense against telomerase RNA and cisplatin for malignant gliomas. Int. J. Oncol. 18, 1287-1292.

LINGNER, J., HUGHES, T.R., SHEVCHENKO, A., MANN, M., LUNDBLAD, V., and CECH, T.R. (1997). Reverse transcriptase motifs in the catalytic subunit of telomerase. Science 276, 561-567.

MAJUMDAR, C., STEIN, C.A., COHEN, J.S., BRODER, S., and WILDO, S.H. (1989). Stepwise mechanism of HIV reverse transcriptase: Primer function of phosphorothioate oligonucleotide. Biochemistry 28, 1340-1346.

MATA, J.E., JOSHI, S.S., PALEN, B., PIRRUCCELLO, S.J., JACKSON, J.D., ELIAS, N., PAGE, T.J., MEDLIN, K.L., and IVERSEN, P.L. (1997). A hexameric phosphorothioate oligonucleotide telomerase inhibitor arrests growth of Burkitt's lymphoma cells in vitro and in vivo. Toxicol. Appl. Pharmacol. 144, 189-197.

MATTHES, E.. and LEHMANN, C. (1999). Telomerase protein rather than its RNA is the target of phosphorothioatemodified oligonucleotides. Nucleic Acids Res. 27, 11521158.

MOELLING, K., SCHULZE, T.. and DIRINGER, H. (1989). Inhibition of human immunodeficiency virus type1 by sulfated polyanions. J. Virol. 63, 5489-5491.

NELSON, J.S., FEARON, K.L., NGUYEN, M.Q., McCURDY, S.N., FREDIANI, J.E., FOY, M.F., and HIRSCHBEIN, B.L. (1997). N3' $\rightarrow$ P5' oligodeoxyribonucleotide phosphoramidates: A new method of synthesis based on a phosphoramidite amine-exchange reaction. J. Org. Chem. 62, 7278-7287.

NORTON, J.C., PIATYSZEK, M.A., WRIGHT, W.E., SHAY, J.W., and COREY, D.R. (1996). Inhibition of human telomerase activity by peptide nucleic acids. Nat. Biotechnol. 14, 615-619.

OHNUMA, T., FENG, L.L., and HOLLAND, J.F. (1997). Inhibitory effects of telomeremimic phosphorothioate oligonucleotides on various human tumor cells in vitro. Anticancer Res. 17, 2455-2458.

PEYMANN, A., and UHLMANN, E. (1996). Minimally modified oligonucleotides-Combination of end capping and pyrimidine-protection. Biol. Chem. Hoppe-Seyler 377, 67-70.

PITTS, A.E., and COREY, D.R. (1998) Inhibition of human telomerase by 2 '-O-methyl-RNA. Proc. Natl. Acad. Sci. USA 95, 11549-11554.

ROCKWELL, P., O'CONNOR, W.J., KING, K., GOLDSTEIN, N.I., ZHANG, L.M., and STEIN, C.A. (1997). Cellsurface perturbations of the epidermal growth factor and vascular endothelial growth factor receptors by phosphorothioate oligodeoxynucleotides. Proc. Natl. Acad. Sci. USA 94, 6523-6528.

SARETZKI, G., SITTE, N., MERKEL, U., WURM, R.E., and VON ZGLINICKI, T. (1999). Telomere shortening triggers a p53-dependent cell cycle arrest via accumulation of G-rich single-stranded DNA fragments. Oncogene 18, 5148-5158.

SHARMA, S., RAYMOND, E., SODA, H., SUN, D., HILSENBECK, S.G., SHARMA, A., IZBICKA, E., WINDLE, 
B., and VON HOFF, D.D. (1997). Preclinical and clinical strategies for development of telomerase and telomere inhibitors. Ann. Oncol. 8, 1063-1074.

SHAY, J.W., and WRIGHT, W.E. (1996). Telomerase activity in human cancer. Curr. Opin. Oncol. 8, 66-71.

STEIN, C.A. (1996). Exploiting the potential of antisense: Beyond phosphorothioate oligonucleotides. Chem. Biol. 3, 319-323.

STEIN, C.A. (1997). Cell-surface perturbations of the epidermal growth factor and vascular endothelial growth factor receptors by phosphorothioate oligodeoxynucleotides. Proc. Natl. Acad. Sci. USA 94, 6523-6528.

TARKANYI, I., HORVÁTH, A., SZATMARY, I., EIZERT, H., VÁMOSI, G., DAMJANOVICH, S., SÉGAL-BENDIRDJIAN, E., and ARADI, J. (2005). Inhibition of human telomerase by oligonucleotide chimeras, composed of an antisense moiety and a chemically modified homo-oligonucleotide. FEBS Lett. 579, 1411-1416.

VU, H., and HIRSCHBEIN, B.L. (1991). Internucleotide phosphite sulfurization with tetraethylthiuram disulfide. tetrahedron Lett. 32, 3005-3008.

WAN, M.S.K., FELL, P.L., and AKHTAR, S. (1998). Syn- thetic 2'-O-methyl-modified hammerhead ribozymes targeted to the RNA component of telomerase as sequence-specific inhibitors of telomerase activity. Antisense Nucleic Acid Drug Dev. 8, 309-317.

ZHANG, X., MAR, V., ZHOU, W., HARRINGTON, L., and ROBINSON, M.O. (1999). Telomere shortening and apoptosis in telomerase-inhibited human tumor cells. Genes Dev. 13, 2388-2399.

Address reprint requests to: Dr. Eckart Matthes Max-Delbriick-Centrum für Molekulare Medizin Robert-Rössle Strasse 10

D-13125 Berlin

Germany

E-mail: emat@mdc-berlin.de

Received March 2, 2005; accepted in revised form August 16, 2005. 